\title{
Knowledge-cum-values Management belongs to the Way out from Global Crisis
}

\author{
Zdenka Ženko, Matjaž Mulej, Vojko Potočan
}

Faculty of Economics and Business, University of Maribor, Maribor, Slovenia

\section{Abstract}

Background: The contemporary world-wide socio-economic crisis tends to escalate and contribute to the global crisis. Limitation of education to one-sided 'knowledge management' rather than socially responsible 'knowledge-cum-valuesmanagement' is one of the crisis's causes. Objectives: The limitations to current knowledge management should be analyzed with systemic thinking. Which values are prevailing in it now and which values will enable the survival of humankind? Methods/Approach: In the first part, literature is reviewed for analysis and conceptual generalization of knowledge management. The theoretical framework based on 'system theory', 'knowledge management' and 'knowledge-cum-values management', and 'values of social responsibility' is introduced. In the second part a new theoretical concept "A potential methodological support for human transition from one-sided to requisitely holistic behavior via social responsibility" is discussed. Results: Knowledge management is a too narrow concept, it tends to leave aside human values, an impact on the natural environment, and extremely growing differences. Humankind needs consideration of responsibility, interdependence and holism in order to minimize detrimental impact of individual behaviour on society, i.e. humans and nature. Conclusions: The research indicates that individuals should attain more requisite holism, and should not be irrational by trying to attain only rationalism in human decision-making and action.

Keywords: knowledge-cum-values management, Dialectical Systems Theory, corporate social responsibility

JEL classification: M10

Paper type: Research article

Received: Nov 10, 2016

Accepted: Feb 04, 2017

Citation: Ženko, Z., Mulej, M., Potočan, V. (2017), "Knowledge-cum-values Management belongs to the Way out from Global Crisis", Business Systems Research, Vol. 8, No. 1, pp. 113-123.

DOI: $10.1515 / \mathrm{bsrj}-2017-0009$

\section{Introduction}

People in life usually have multiple, but positively oriented goals: (i) to have and/or to be reliable partners both in business and labor relations; (ii) to prevent no expected cost; (iii) to act for the long-term and less selfish goals; (iv) to preserve your own, your children's and your grandchildren's natural preconditions of life, and others. 
However, the most influential humans and organizations seem to choose the opposite: the arm race and related business generate huge profits, influencing large number of human losses and migrants. This means that some most influential actors do not take into account social responsibility, i.e.: holism, interdependence and responsibility, which the current humankind has chosen as the crucial preference by passing ISO 26000 (ISO, 2010) etc. (see e.g. Mulej et al., 2013d; Ženko et al., 2013a; Mulej et al., 2013a; Mulej et al., 2016; Mulej et al., 2014; etc.). Their knowledge might be very professional, but one-sided, if their values let them behave as they do, causing the recent world-wide socio-economic crisis from 2008 by promotion of monopolies under the label of free market.

On one hand humankind created United Nations in order to never repeat the terrible period with two world wars and the global depression between them (19141945). But the most influential persons and organizations have obviously forgotten about that and the L. V. Bertalanffy's warning, that he expressed as creator of Systems Theory (right after that period that he had experienced WWII). He believed that the fate of the world depends from the possibility of adoption by humanity of a new set of values, which are based on the general systems Weltanschauung (= worldview). Bertalanffy wrote, that we are seeking another basic outlook of the world as organization (Davidson, 1983, quoted from: Elohim, 1999, in Mulej et al., 2013b).

Hence, humankind needs systemic requisitely holistic behavior that includes thinking and feeling, reaching beyond the one-sided knowledge management. A clear case of an influential limitation to knowledge management: Mazour, Chumakov, and Gay (2003), defined the Globalization in the "Global Studies Encyclopedia", : "Globalization is amalgamation of national economies into united world system based on rapid capital movement, new informational openness of the world, technological revolution, adherence of the developed industrialized countries to liberalization of the movement of goods and capital, communicational integration, planetary scientific revolution, international social movements, new means of transportation, telecommunication technologies and internationalized educationı, (quoted from: Ečimović et al., 2016). - Humans and nature are not visible.

Knowledge management is a too narrow concept; it tends to leave aside human values and other emotions, impact over the humankind's natural environment, the extremely growing differences (and their consequences, such as migrations around the world). The given situation requires transition to 'knowledge-cum-values management' exposing interdependence of these two crucial human attributes. The transition needs some bases, process and methodological support. They are briefed here.

We live in a globalized world. The above addressed dilemmas are open and crucial for survival in this world; the daily press is publishing the warnings, many wars are going on, migrants are around in tens of millions, millions are dying due to hunger, unhealthy water and air, nearly a hundred million people need international aid to survive; etc. There is as much knowledge around as never before. Obviously, it is too one-sided to cause good life. The research question hence reads: how can one link human knowledge and values to accomplish the requisite holism instead of the prevailing dangerous one-sided behavior.

As the research method we used in the first part analysis of literature for conceptual generalization. The theoretical framework is based on dialectical system theory as a methodology of requisite holism of interdisciplinary creative cooperation 
in human work. The theoretical concepts of knowledge management and knowledge-cum-values management, importance of values, and social responsibility are introduced. In the second part a new theoretical concept "A potential methodological support for human transition from one-sided to requisitely holistic behavior via social responsibility" is discussed.

\section{Literature review}

\section{Knowledge management and knowledge-cum-values management}

For methodological approach we have used conceptual generalization in the first part of research. The theoretical framework based on 'system theory', 'knowledge management' and 'knowledge-cum-values' management, values of social responsibility is introduced for the goal of this research. In the second part a new theoretical concept "A potential methodological support for human transition from one-sided to requisitely holistic behavior via social responsibility" will be discussed.

Another modern idea the "new economy", addressing economics of surviving and sustainable development of modern societies and their organizations does not address Knowledge-cum-Values either (Leydesdorff, 2006; Carayannis et al., 2009; Howkins, 2001; Dubina et al., 2012; Leiponen et al., 2010; Korten, 2009; Lafley et al., 2010; Ralston et al., 2011 ; Ralston et al., 2014). Closer might be discussions regarding the importance of knowledge and education for necessary reliance of intellectual capabilities for development of knowledge-intensive activities (Drucker, 1969; Powell et al., 2004; Mandel et al., 2016). Several authors expose importance of co-evolution between knowledge, innovation and creativity (Peterman et al., 2003; Carayannis et al., 2014; Potočan et al., 2014; Rašič, 2015; Zore, 2015).

Similarly, management studies about utilization of "new economy" in organizations do not address knowledge-cum-values (Teece, 1998; Botsaris et al., 2016; Kaufman, 2015). Researches rather emphasized importance of the "developers of knowledge" for economic growth and welfare of society (Drucker, 1969; Carayannis et al., 2009; Tidd et al., 2009; Carayannis et al., 2014; Kuratko, 2016). But Camelo-Ordaz et al. (2012) exposed influence of entrepreneurs' demographic attributes and human values about innovation success in creative small firms.

\section{The role of values in the human work process}

The work process makes humans differ from other living beings. It requires and develops rational behavior for humans to survive, but life shows the rational and irrational human attributes' interdependence, like right and left part of brain, in management of human activities. In Mulej's 'Dialectical Systems Theory' as a methodology to support the requisitely holistic behavior this process is summarized as shown in Table 1. 


\section{Table 1}

The law of hierarchy of succession and interdependence, applied to the work procedure in general

$\rightarrow$ External influences, preconditions, circumstances + ones' own knowledge-cumvalues $\rightarrow$

$\rightarrow$ Perceived influences, preconditions and circumstances $\rightarrow$

$\rightarrow$ Definition and development of starting points as requisitely holistic system $\rightarrow$

\section{The external} starting points, part 1: objective / outer needs

$\leftrightarrow$ The subjective starting points for the

given case: $\leftrightarrow$

1. Values and other emotions (what part 2: objective / for? preference)

2. Knowledge on contents of what \& why?

3. Knowledge on methods of how \& why?

4. Talents

The dialectical system of essential viewpoints $\rightarrow$ $\rightarrow$ The selected viewpoint/s $\rightarrow$

$\rightarrow$ Selection of the perceived objective need \& perceived objective possibilities $\rightarrow$ $\rightarrow$ Selection of preferential needs \& corresponding possibilities $\rightarrow$

$\rightarrow$ Definition of well, i.e. requisitely holistically grounded, not merely desired! objectives/goals:

What do we want (with good reason/s)? $\rightarrow$

$\rightarrow$ Definition of tasks system/s: What do we have to do in order to attain objectives/goals? $\rightarrow$

$\rightarrow$ Definition of work procedures for every task: How must we proceed to perform?

$\rightarrow$ Operation: performing all the tasks according to the procedures prescribed/foreseen $\rightarrow$

$\rightarrow$ Results comparable to tasks, each of them contributing to attainment of objectives/goals $\rightarrow$

$\rightarrow$ Influence over the foregoing phases of the process where needed (returning to the beginning of the entire process or to a phase of it) $\rightarrow$ Source: Authors' illustration prepared and updated from (Mulej, 1979 and 2013)

Table 2 summarizes how values of the influential person become more or less general and direct the human practical behavior (Mulej et al., 2009, Mulej et al., 2013a, Ženko et al., 2013b).

Table 2

Interdependence of values, culture, ethics, and norms

\begin{tabular}{lll}
\hline $\begin{array}{l}\text { Individual with knowledge } \\
\text { interdependent values }\end{array}$ & $\rightarrow$ & Culture as values shared by many \\
\hline \multicolumn{1}{c}{$\uparrow$} & $\times$ & \\
$\begin{array}{l}\text { Norms as prescribed ethics about } \\
\text { right and wrong in a social group }\end{array}$ & $\leftarrow \begin{array}{l}\text { Ethics as prevailing culture about right } \\
\text { and wrong in a social group }\end{array}$ \\
\hline
\end{tabular}

Source: Authors' illustration 
The point of consideration of knowledge-cum-values management instead of knowledge management lies in the necessary transition from one-sided consideration of humans to the requisitely holistic one, which prevents the crucial oversights better than a one-sided one, while a real, i.e. total holism cannot be reached.

In practice, values are very crucial: they do depend on knowledge, but they also influence knowledge, all the way to the selection for which purpose a given knowledge is applied.

\section{Dialectical Systems Theory}

Dialiectical Systems Theory (DST) matches criteria of requisite holism (Mulej et al., 2013a). The three relations in DST are: (i) The law of requisite holism, (ii) The law of entropy, and (iii) The law of hierarchy of succession and interdependence.

The three elements in DST are: (i) The ten guidelines defining the subjective starting points (values and other emotions, knowledge on contents, and knowledge on methods, as a dialectical system) aimed at making humans go for creativity and holism rather than for routine-loving and one-sided behavior; (ii) The ten guidelines on assuring the agreed policy to survive in later steps of the working process (in which several more narrowly specialized and routine-loving persons normally enter the stage); and (iii) A methodology of creative cooperation aimed at making DST viable in the daily practice as an informal systems-thinking by a shared framework programming and executing of the human creative activities (e.g., our own method called USOMID in Slovene acronym).

\section{Adam Smith as the crucial author of the economic theory}

Adam Smith wrote the "Theory of Moral Sentiments" (1759) firs and later on his book "An Inquiry into the Nature and Causes of the Wealth of Nations" (1776). He was a professor of ethics and moral and presumed that ethics of altruism would help people to overcome their natural selfishness, which makes them forget solidarity and interdependence, if they experience that narrow individualism might help them better than solidarity.

Even today many people consider altruism less appealing. But today we can replace it, in the very competitive business world with values culture ethics and norms (VCEN) of interdependence. In practical life we can recognize it as creditworthiness and trustworthiness and credibility and reliability - for clear economic reasons (Ženko et al., 2013b).

Adam Smith's 'invisible hand' does not express one-sidedness of the business partners: reliable partners keep their partners, who return again and again to do business and generate profit with relatively low cost and effort that is smaller than the effort to find new high-quality employees, suppliers, buyers and other partners, than the strikes, the illness, the poor productivity, or absenteeism, presentism, consequences of monopolies, both on the part of governments and enterprises, etc. They behave in interdependence and with long-term views, e.g. in customer fidelity.

\section{Discussion}

\section{Reflection of the above findings in social responsibility}

Systems theory has many versions (François, 2004). Many of system theories consider only selected parts of reality from their selected viewpoints. Thus, many of them, although useful and beneficial, deviate from the basic difference of systems theory 
and cybernetics from the traditional sciences and practices: to fill in the gap in human knowledge and values resulting from oversights caused by overspecialization and lack of inter-disciplinary creative cooperation (Bertalanffy, 1951/1968, edition 1979; Wiener, 1948, edition 1985). Thus, creative cooperation leads toward the requisite holism as the solution for humankind to never repeat the world wars and big recession of 1914-1945. Now, a similar dangerous crisis is here, as the daily press reports. Solution requires requisitely holistic management of human knowledge and values.

In order to overcome the present global social and economic crisis, humankind must overcome two types of crisis: (1) oversights due to the narrowly specialized and poorly cooperating persons' non-systemic behavior and its management; (2) overspecialization inside systems theory and cybernetics causing fictitiously systemic behavior and its management.

For four decades, we have been offering a solution by Mulej's Dialectical Systems Theory (Mulej, 1974; Mulej et al., 2013; many publications between them and latter) with many thousands of successful cases of applications. Though, our cases were more often local than global.

Now, a new solution is offered on the world-wide level: (corporate) social responsibility that supports systemic behavior (not thinking only), informally (ISO 26000 standard, by ISO, 2010); it covers all topics of human activity and exposes seven principles of systemic behavior.

ISO standard 26000 (ISO, 2010) includes the requirement of a holistic approach, which is based on interdependence. This standard includes seven content areas: (1) organization, management and governance, (2) human rights, (3) labor practices, (4) environment, (5) fair operating practices, (6) consumer issues, and (7) community involvement and development.

This requirement of holistic approach in this standard is supported by the seven principles: A. Accountability, B. Transparency, C. Ethical behavior, D. Respect for stakeholder interests, E. Respect for the rule of law, F. Respect for international norms of behavior, and $G$. Respect for human rights (ISO 2010: 10-14).

European Union (2011) supports social responsibility as responsibility of an individual for her/his impact over society. European Union recommends its member states and enterprises to be role models and act socially responsible. All these contents link two crucial terms from the (Dialectical) Systems Theory: interdependence, and holism. They crucially change the prevailing current VCEN practices.

Obviously, an innovation of values by knowledge-cum-values management is demanded. It should receive methodologically support.

\section{A potential methodological support for human transition from one- sided to requisitely holistic behavior via social responsibility}

With social responsibility VCEN become important for companies not only since they are required by regulations and laws, but because they recognize their competitive advantage with their more requisitely holistic business. Methodologically, we have selected and combined two methods for creative thinking and decision making: The Six Thinking Hats of De Bono and USOMID' as summarized in Table 4. De Bono's methods for 'parallel thinking' and method 'Six Thinking Hats' support lateral way of thinking and cooperative behavior (De Bono, 2005, 2006, 2015).

Six thinking hats have each a different color that represents a diferetn way of thinmking. They should be applied in phases. All participants use the same hat at the 
same time in the same phase, and then all switch to another hat and a new way of thinking. First blue hat encourages thinking about organization, control of the process, discipline. Questions are what topic to discuss, what we want to achieve... Next can be white (neutral) hat encouraging objective facts, information about what is known with no interpretation. Red hat allows expressing feelings, emotions, views, intuition without explaining why, or justification. Yellow hat encourages optimistic thinking, search for benefits, advantages of proposals, search for implementation ways, constructive approach. Black hat allows negative thoughts, being cautions, expressing doubt, weak points, critique, potential problems, disadvantages, negative sides. Green hat represents energy and encourages novelty, creation, ideas, alternatives, possibilities to solve all problems. The end blue hat includes reading of results, necessary conclusions.

They can help governors and managers to run their region and organizations with requisite holism and hence successfully (see Mulej et al., 2013a, for details and references).

Table 4

Synergy of USOMID/SREDIM and Six Thinking Hats methodologies in procedure of USOMID

\begin{tabular}{|c|c|c|c|c|c|c|}
\hline $\begin{array}{l}\text { SREDIM } \\
\text { Phases } \\
\text { USOMID } \\
\text { Steps } \\
\text { Inside } \\
\text { SREDIM } \\
\text { Phases }\end{array}$ & $\begin{array}{l}\text { 1. } \\
\text { Select } \\
\text { problem / } \\
\text { oppor- } \\
\text { tunity to } \\
\text { work on in } \\
\text { an } \\
\text { USOMID } \\
\text { circle }\end{array}$ & $\begin{array}{l}\text { 2. Record } \\
\text { data } \\
\text { about the } \\
\text { selected } \\
\text { topic (no } \\
\text { 'Why') }\end{array}$ & $\begin{array}{l}\text { 3. Evaluate } \\
\text { recorded } \\
\text { data on the } \\
\text { topic ('Why } \\
\text { is central') }\end{array}$ & $\begin{array}{l}\text { 4. Determine } \\
\text { and develop } \\
\text { chosen } \\
\text { solution/s to } \\
\text { the topic }\end{array}$ & $\begin{array}{l}5 . \\
\text { Imple-ment } \\
\text { chosen } \\
\text { solution to } \\
\text { the topic in } \\
\text { reality }\end{array}$ & $\begin{array}{l}\text { 6. Maintain } \\
\text { implemen- } \\
\text { ted solution } \\
\text { for a } \\
\text { requisitely } \\
\text { long term }\end{array}$ \\
\hline $\begin{array}{l}\text { 1. Individual } \\
\text { brain-writing } \\
\text { by all in the } \\
\text { organisational } \\
\text { unit / circle }\end{array}$ & All 6 hats & White hat & $\begin{array}{l}\text { All } 6 \text { hats, } \\
\text { red, black, } \\
\text { yellow, } \\
\text { green first } \\
\text { of all }\end{array}$ & $\begin{array}{l}\text { All } 6 \text { hats, red, } \\
\text { black, yellow, } \\
\text { green first of } \\
\text { all }\end{array}$ & $\begin{array}{l}\text { All } 6 \text { hats in } \\
\text { prepara- } \\
\text { tion of } \\
\text { imple- } \\
\text { mentation }\end{array}$ & $\begin{array}{l}\text { All } 6 \text { hats in } \\
\text { prepara- } \\
\text { tion of } \\
\text { mainte- } \\
\text { nance }\end{array}$ \\
\hline $\begin{array}{l}\text { 2. Circulation } \\
\text { of notes for } \\
\text { additional } \\
\text { brain-writing } \\
\text { by all }\end{array}$ & All 6 hats & White hat & $\begin{array}{l}\text { All } 6 \text { hats, } \\
\text { red, black, } \\
\text { yellow, } \\
\text { green first } \\
\text { of all }\end{array}$ & $\begin{array}{l}\text { All } 6 \text { hats, red, } \\
\text { black, yellow, } \\
\text { green first of } \\
\text { all }\end{array}$ & $\begin{array}{l}\text { All } 6 \text { hats in } \\
\text { prepara- } \\
\text { tion of } \\
\text { imple- } \\
\text { mentation }\end{array}$ & $\begin{array}{l}\text { All } 6 \text { hats in } \\
\text { prepara- } \\
\text { tion of } \\
\text { mainte- } \\
\text { nance }\end{array}$ \\
\hline $\begin{array}{l}\text { 3. Brain- } \\
\text { storming for } \\
\text { synergy of } \\
\text { ideas / } \\
\text { suggestions }\end{array}$ & All 6 hats & White hat & $\begin{array}{l}\text { All } 6 \text { hats, } \\
\text { red, black, } \\
\text { yellow, } \\
\text { green first } \\
\text { of all }\end{array}$ & $\begin{array}{l}\text { All } 6 \text { hats, red, } \\
\text { black, yellow, } \\
\text { green first of } \\
\text { all }\end{array}$ & $\begin{array}{l}\text { All } 6 \text { hats in } \\
\text { preparation } \\
\text { of imple- } \\
\text { mentation }\end{array}$ & $\begin{array}{l}\text { All } 6 \text { hats in } \\
\text { prepara- } \\
\text { tion of } \\
\text { mainte- } \\
\text { nance }\end{array}$ \\
\hline $\begin{array}{l}\text { 4. Shared } \\
\text { conclusions of } \\
\text { the circle }\end{array}$ & All 6 hats & White hat & $\begin{array}{l}\text { All } 6 \text { hats, } \\
\text { red, black, } \\
\text { yellow, } \\
\text { green first } \\
\text { of all }\end{array}$ & $\begin{array}{l}\text { All } 6 \text { hats, red, } \\
\text { black, yellow, } \\
\text { green first of } \\
\text { all }\end{array}$ & $\begin{array}{l}\text { All } 6 \text { hats in } \\
\text { preparation } \\
\text { of imple- } \\
\text { mentation }\end{array}$ & $\begin{array}{l}\text { All } 6 \text { hats in } \\
\text { prepara- } \\
\text { tion of } \\
\text { mainte- } \\
\text { nance }\end{array}$ \\
\hline
\end{tabular}

Source: Authors' illustration, quoted for brief clarification (Mulej et al., 2013a)

A brief comment: there are six phases of the human work processes. For the requisite holism creative cooperation is necessary in all six phases. These two facts show the process as a table with 24 work steps. The application of the 'six thinking hats method' in every one of them can improve the efficiency of the process very 
much, experience says. It also helps the team members apply 'knowledge-cumvalues' rather than the too narrow knowledge management.

\section{Concluding remarks}

Values and other emotions are normal human attributes, but the economic theory, except Adam Smith who was a professor of moral and ethic, tends to oversimplify its models by averages and by leaving values and emotions aside (see also: Piketty, 2015, p. 30). The literature on management theory is hardly more realistic by limiting itself to 'knowledge management' rather than the concept of 'knowledge-cum-values management'. Knowledge management is a too narrow concept; it tends to leave aside human values, impact over the natural environment, and extremely growing differences. Humankind needs consideration of responsibility, interdependence and holism in order to minimize one's detrimental impact over society, i.e. humans and nature.

To our research question: how can one link human knowledge and values to attain the requisite holism instead of the dangerous one-sidedness we have found that we can develop into applying more knowledge-cum-values management. A realistic approach requires consideration of Mulej's 'Dialectical Systems Theory' that has been applied in several thousand cases, or, maybe even better, the '(Corporate) Social Responsibility' that is an informal way to the same goal: the requisitely holistic behavior, based on VCEN of interdependence, supported with the seven social responsibility priciples from ISO 26000 and the methods of creative cooperation, like Mulej's USOMID and De Bono's 'parallel thinking' with 'Six Thinking Hats' attaining lateral thinking and cooperative behavior.

\section{References}

1. Bertalanffy, L. (1979). General Systems Theory, Foundations, Development, Applications, New York, Braziller.

2. Botsaris, C., Vamvaka, V. (2016), "Attitude toward Entrepreneurship: Structure, Prediction from Behavioral Beliefs, and Relation to Entrepreneurial Intention", Journal of Knowledge Economy, Vol. 7 No. 2, pp. 433-460.

3. Camelo-Ordaz, C., Fernandez-Alles, M., Ruiz-Navarro, J., Sousa-Ginel, E. (2012), "The Intrapreneur and Innovation in Creative Firms", International Small Business Journal, Vol. 30 No. 5, pp. 513-535.

4. Carayannis, E. G., Pirzadeh, A., Popescu, D. (2014). Institutional Learning and Knowledge Transfer across Epistemic Communities: New Tools of Global Governance, New York, Springer.

5. Carayannis, E., Campbell, D. (2009), ","Mode 3" and "Quadruple Helix": Toward a $21^{\text {st }}$ century fractal innovation ecosystems", International Journal of Technology Management, Vol. 46 No. 3-4, pp. 201-234.

6. De Bono, E. (2005), "Šest klobukov razmišljanja (Six Thinking Hats, in Slovene)", New Moment, No. 28 (entire journal).

7. De Bono, E. (2006), "Lateralno razmišljanje (Lateral Thinking, in Slovene)", New Moment, No. 30 (entire journal).

8. De Bono, E. (2015). Enostavnost $\vee$ razmišljanju (Simplicity in Thinking, in Slovene), Maribor, Založba Rotis.

9. Drucker, P. (1969). The Age of Discontinuity: Guidelines to Our Changing Society, New York, Harper and Row. 
10. Dubina, I., Carayannis, E., Campbell, D. (2012), "Creativity Economy and a Crisis of the Economy? Coevolution of Knowledge, Innovation, and Creativity, and of the Knowledge Economy and Knowledge Society", Journal of Knowledge Economy, Vol. 3 No.1, pp. 1-24.

11. Ečimović, T., Mulej M., et al. (2016), "The Sustainability and World Governing for Better Tomorrow and Survival of Homo sapiens Civilization", in Proceedings of the 12 ECPD International Conference "Future of the World between Globalization and Regionalization", Belgrade, October $28^{\text {th }}$ and $29^{\text {th }} 2016$.

12. European Union (2011), "Communication from The Commission to The European Parliament, The Council, The European Economic and Social Committee and The Committee of the Regions: A Renewed EU Strategy 2011-14 for Corporate Social Responsibility", European Commission, Com (2011) 681 Final, Brussels.

13. François, C. (Ed.) (2004). International Encyclopedia of Systems and Cybernetics, Munich, Saur.

14. Howkins, J. (2001). The creative economy: How people make money from ideas, London, Penguin.

15. International Standard Organization (2010), "ISO 26000", available at: http://www.iso.org/iso/ discovering_iso_26000.pdf (10 October 2016)

16. Kaufman, B. E. (2015), „Market competition, HRM, and firm performance: The conventional paradigm critiqued and reformulated", Human Resource Management Review, Vol. 25 No. 1, pp. 107-125.

17. Korten, D. (2009), Agenda for a New Economy: From Phantom Wealth to Real Wealth, San Francisco, Berrett-Koehler.

18. Kuratko, D. (2016). Entrepreneurship: Theory, Process, and Practice, Nashville, Cencage/South-Western Publisher.

19. Lafley, A., Johnson, M. (2010). Seizing the White Space: Business Model Innovation for Growth and Renewal, Boston, Harvard Business Press.

20. Leiponen, A., Helfat, C. (2010), "Innovation objectives, knowledge sources, and the benefits of breadth", Strategic Management Journal, Vol. 31 No. 2, pp. 224236.

21. Leydesdorff, L. (2006). The Knowledge-based Economy, Boca Raton, Universal Publishers.

22. Mandel, R., Noyes, E. (2016), „Survey of experiential entrepreneurship education offering among top undergraduate entrepreneurship programs", Education + Training, Vol. 58 No. 2, pp. 164-178.

23. Mulej, M. (1979). Ustvarjalno delo in dialektična teorija sistemov (Creative Work and the Dialectical Systems Theory, in Slovenian), Celje, Razvojni center.

24. Mulej, M. and 14 coauthors, (2013a). Dialectical Systems Thinking and the Law of Requisite Holism concerning Innovation, Litchfield Park, Arizona, Emergent Publications.

25. Mulej, M., Dyck, M. (Eds.) (2014). Social responsibility beyond neoliberalism and charity, Shirjah, UAE, Bentham Science.

26. Mulej, M., Hrast, A., Ženko, Z. (2013b), "Social Responsibility - measures and measurement", Systems Practice and Action Research, Vol. 26 No. 6, pp. 475484.

27. Mulej, M., Merhar, V., Žakelj, V., Hrast, A., Čagran, B. (Eds.) (2016), Nehajte sovražiti svoje otroke in vnuke, 3 volumes, in Slovene, IRDO and Kulturni center Maribor.

28. Mulej, M., Ženko, Z., Dyck, R., Ženko, Z. (Eds.) (2013d). Systemic practice and action research, New York, Plenum Press. 
29. Mulej, M., Ženko, Z., Potočan, V. (2009), "Odprto inoviranje" namesto "zaprtega inoviranja" = 'Open innovation' replaces 'closed innovation'. Naše gospodarstvo, Vol. 55 No. 1-2, pp. 76-84.

30. Peterman, E. N., Kennedy, J. (2003), „Entreprise Education: Influencing Students' Perceptions of Entrepreneurship", Entrepreneurship Theory and Practice, Vol. 28 No. 2, pp. 129-144.

31. Piketty, T. (2015). Kapital $\vee 21$. Stoletju (Original: Le capital au XXle siẻcle, Slovene edition), Ljubljana, Mladinska knjiga.

32. Potočan, V., Nedelko, Z. (2014), "Management innovativeness: A case of Slovenian small and medium enterprises", Transformations in Business and Economics, Vol. 13 No. 1, pp. 41-59.

33. Powell, W., Snellman, K. (2004), "The Knowledge Economy", Annual Review of Sociology, Vol. 30 No.1, pp. 199-220.

34. Ralston, D., Egri, C., Furrer, O., Mockaitis, A. et al. (2014), "Societal-Level Versus Individual-Level Predictions of Ethical Behavior: A 48-Society Study of Collectivism and Individualism", Journal of Business Ethics, Vol. 122 No. 2, pp. 283-306.

35. Ralston, D., Egri, C., Reynaud E., Srinivasan, N., et al. (2011), „A Twenty-First Century Assessment of Values across the Global Workforce", Journal of Business Ethics, Vol. 104 No. 1, pp. 1-31.

36. Rašič, K. (2015), "Sistem indikatorjev tehnično-tehnoloških raziskav, inovativnosti in znanja na primeru tranzicijskega gospodarstva", PhD dissertation, Maribor, Univerza $\vee$ Mariboru, Ekonomsko-poslovna fakulteta.

37. Smith, A. (1759, ed. 2000). The Theory of Moral Sentiments, Prometheus Books, New York.

38. Smith, A. (1776, ed. 1998). An Inquiry into the Nature and Causes of the Wealth of Nations, Modern Library, New York.

39. Teece, D. (1998), "Capturing value from knowledge assets: The new economy, markets for know-how, and intangible assets", California management review, Vol. 40 No. 3, pp. 55-79.

40. Tidd, J., Bessant, J. (2009). Managing innovation: Integrating Technological, Market and Organizational Change, Hoboken, New Jersey, John Wiley and Sons.

41. Wiener, N. (1985). Cybernetics or control and communication in the animal and the machine, Cambridge, Mass, M.I.T. Press.

42. Ženko, Z., Hrast, A., Mulej, M. (2013a), "Social responsibility: measures and measurement as a basis for organizational systemic action", Systemic practice and action research, Vol. 26 No. 6, pp. 475-484.

43. Ženko, Z., Mulej, M., Mulej, N., Hrast, A., (2013b), "Solving the economic crisis with (requisitely) holistic approach and (ethics of) interdependence", Business Systems Review, ISSN 2280-3866, 2013, Vol. 2 No. 2, pp. 10-35.

44. Zore, M. (2015), "Krepitev inovativnosti podjetij $\vee$ Sloveniji z razvojem družbene odgovornosti", PhD dissertation, Maribor, Univerza $\vee$ Mariboru, Ekonomskoposlovna fakulteta. 


\section{About the authors}

Zdenka Ženko, Ph.D. is a Full Professor of Governance and strategic management at the Faculty of Economics and business, University of Maribor. She was employed in Apis, Jozef Stefan Institute, Lek pharmaceuticals, ASUCLA, and Tehnološki transfer (manager and 51\% owner). Doctoral thesis: "Comparative analysis of management models in Japan, USA, and Western Europe". Shorter or longer she worked and acquired knowledge in Czech Republic, Greece, Belgium, USA, Austria, Ukraine, Finland. Her research interests: innovating, creativity, methods for creative thinking and decision making and ethics with systems theory for holistic understanding and problem solving based on ethical and sustainable socially responsible innovating. She can be contacted at zdenka.zenko@um.si

Matjaz Mulej, Ph.D. Ph.D. is a Professor Emeritus of Systems and Innovation Theory (applied also to social responsibility for +10 years) at Faculty of Economics and business, University of Maribor. He has +1.800 publications in +40 countries (see: IZUM/Cobiss/Bibliographies, 08082). Visiting professor abroad: 15 semesters. Author: Dialectical Systems Theory (see: François, 2004, International Encyclopedia...); Innovative Business Paradigm and Methods. Member: European Academy of Sciences and Arts, Salzburg (2004), European Academy of Sciences and Humanities, Paris (2004), International Academy for Systems and Cybernetic Sciences, Vienna (2010; former head). M.A. in Development Economics, Doctorates in Economics/Systems Theory, and in Management/Innovation Management. He can be contacted at matjaz.mulej@um.si

Vojko Potocan, Ph.D. (in Business) is a Full Professor of Management at the Faculty of Economics and Business (FEB), University of Maribor (Slovenia). He teaches in 3 universities in Slovenia and in 3 universities abroad. He takes part in different international scientific conferences and has conducted a number of study visits abroad. He has published over 400 texts (over 300 in foreign languages in 40 countries), including 8 books. Dr. Potocan has published over eighty articles in peer reviewed scholarly journals including but not limited to Journal of International Business Studies, Journal of business ethics, and Journal of world business. He can be contacted at vojko.potocan@um.si 